Article

\title{
Tree Belts for Decreasing Aeolian Dust-Carried Pesticides from Cultivated Areas
}

\author{
Eli Zaady ${ }^{1, *}$, Itzhak Katra ${ }^{2}$, Shimshon Shuker ${ }^{1}$, Yaakov Knoll ${ }^{1}$ and Sarig Shlomo ${ }^{3}$ \\ 1 Department of Natural Resources, Agricultural Research Organization, Institute of Plant Sciences, Gilat \\ Research Center, Mobile Post Negev 8531100, Israel; Shuker@volcani.agri.gov.il (S.S.); \\ yaakovmi@post.bgu.ac.il (Y.K.) \\ 2 Department of Geography and Environmental Development, Ben-Gurion University of the Negev, \\ Beer Sheva 84105, Israel; katra@bgu.ac.il \\ 3 The Katif Research Center, Sdot-Negev, Mobile Post Negev 85200, Israel; shlomosarig@gmail.com \\ * Correspondence: zaadye@volcani.agri.gov.il; Tel.: +972-8-9928658
}

Received: 29 June 2018; Accepted: 24 July 2018; Published: 30 July 2018

\begin{abstract}
The aim of this study was to investigate the function of tree belts in reducing the aeolian transport of dust particles carrying pesticides. The study examined the importance of the buffer zones created by commonly planted trees (Eucalyptus camaldulensis, Pinus halepensis (pine) and Ceratonia siliqua (carob)). The methods include analyzing the quantity and the chemical composition of pesticides carried by aeolian dust particles from the intensively cultivated fields and orchards, where pesticides were applied, towards the tree belts nearby. Eighteen different chemicals used as insecticides, fungicides and herbicides, were found both in the agricultural fields and in the adjacent tree belts, suggesting an important function of the trees. This ecological service has rarely been taken into consideration by management policies of tree plantings in farmland areas. To integrate this service into agriculture, especially in the case of agricultural fields and orchards, which are adjacent to populated areas, planting tree belts should be positively considered as a means for reducing aeolian dust and air pollution, mainly in order to reduce leakage of pesticides, which are a cause for significant health concerns.
\end{abstract}

Keywords: leakage; buffer strips; airborne dust; wind barriers; windbreaks

\section{Introduction}

The various activities conducted in intensive agriculture result in increased use of pesticides. These chemicals are used in the field to reduce crop damage by agricultural pests such as insects, weeds, fungi and rodents. The growing use of pesticides has produced great benefits of increased food production and achievement of food security for the world growing population (http:/ / www.fao. org/state-of-food-security-nutrition). It is estimated that 2.5-3.5 million tons of pesticides are applied annually to agricultural crops around the world [1,2]. The increased use of pesticides is associated with increased environmental exposure risks.

Pesticides have become a source of soil, aerial and water pollutants. Concerns regarding their effects on the environment and on human health began to rise in the early 1960s [3]. Essential information about the environmental consequences of prolonged exposure to these materials, not only in humans but also in adjacent natural ecosystems [2], is still lacking. However, there is a consensus that the damage caused by pesticide exposure depends on the rate and the level of exposure and on the toxic properties of the substance $[4,5]$.

As a result of these detrimental effects, and thanks to improving technologies, regulation and monitoring of pesticide residues in imported agricultural products has increased, mainly in the EU [6], 
creating further difficulties for agricultural production. This can even affect farmers who do not exceed the allowed amounts of pesticides, since residues may drift by wind and/or water from the surrounding fields $[7,8]$. The definition of the permitted levels of pesticide residues in agricultural products has recently become more stringent. For example, residues of certain pesticides, which were formerly analyzed in concentrations of parts per million $(\mu \mathrm{g} / \mathrm{g})$ in crop products are currently a cause for rejection even at concentrations of parts per billion (ng/g). With increased control of pesticide residues in agricultural products and improved testing measures, there is a growing public demand to reduce the use of pesticides to the minimum necessary and to use environmentally-friendly compounds. The extensive use of pesticides is mainly made by farmers, but also by various non-agricultural authorities such as railway companies and road construction corporations and local councils, who, for example, use herbicides for cleaning roadside channels [9] and spray wetland insecticides in the summer against mosquitoes.

The pesticides administrated in the field either to the crop or directly to the soil may undergo various processes. They may be decomposed, evaporated into the atmosphere, transported with the surface water flow, leaked to the groundwater, absorbed by plants, organic matter and organisms in the soil, or remain attached to the soil surface particles [7]. In contrast, atmospheric evaporation losses, measured within a few days after application, are about $80 \%[7,10]$. The dispersion and presence of pesticides in the atmosphere may occur over very long distances, as evidenced by the presence of pesticides in the mist above the ocean [11,12], and in the Arctic snow areas [13]. In the soil, the survival of pesticides can be affected by several variables: (1) the rate of degradation by microorganisms, which is strongly affected by soil moisture and temperature [14]; (2) chemical and photochemical decomposition; (3) adsorption and binding to organic matter and mineral particles of the soil, affected by soil properties and the molecular structure of the pesticide. In this case the pesticides may diffuse to the environment via soil erosion by wind [15]. It has been shown that about $20 \%$ of pesticides or decomposition derivatives are associated with soil particles [16]. The influencing factors in this case are mostly: climate (temperature and distribution of rainfall), especially in the first weeks after application; application rate and application season [10]; (4) absorption by plant roots, which is the main path for pesticides to enter the food chain, exposing humans and animals that feed on them to their toxicity [17]; (5) transportation through overland runoff and leakage to nearby areas or into groundwater.

The Environmental Protection Agency (EPA) [18] has developed stringent regulations specifying restrictions on the use of toxins and harmful chemicals by ground application, tractor mounted sprayers, boom sprayers and aerial spraying. Currently, the regulations restrict pesticide use only in the vicinity of residential areas, but do not include regulations for natural areas, despite the implications for flora and fauna. In order to reduce pesticide spray drifts, several technologies have been developed, mostly regarding the form of application of pesticides, from the ground or by aerial spraying $[18,19]$. Others deal with the construction of buffer zones for various field conditions [8,20-22]. The method of building "vegetative filter strips" was tested by Sabbagh et al. [22]. The effectiveness of these strips, located at the lower edges of fields, was found to be high in some cases but not as good in other cases (Popov et al. [23]). Another method was the construction of such buffer strips in the middle of the sprayed fields. This method was found to be much less effective, as it was inefficient in reducing pesticides in runoff water that can reach adjacent fields, creeks, reservoirs and groundwater [24].

The increasing human population, urbanization, and expansion of farmlands produce a mosaic of agricultural fields and orchards in natural areas and agricultural communities. The increased intensity of land use has resulted in new agriculture areas, including semi-arid regions, where wind is the major force of soil erosion [25]. This requires the use of windbreaks such as tree belts around sensitive cultivated fields and plantations. The impacts on crop size and yield, considering the aerodynamics of windbreaks as sheltering field crops from the wind, have been well documented [8,26-30]. An optimal vegetative barrier lowers wind speed, allowing air to pass through tree foliage while filtering out aeolian particles [31]. 
Leonard [16] reported that pesticides are associated with soil particles while others [31] reported that trees lower wind speed and may affect aeolian particle accumulation. A recent study has showed that airborne particle absorption by semi-arid forests reduces particulate matter (PM) pollution in nearby urban environments during dust storms [32,33]. These findings led us to suggest that using trees as windbreaks may not only reduce wind speed and filter out aeolian dust particles, but moreover and consequently, reduce pesticide dispersal. Apparently, the notion of reducing pesticides carried by aeolian dust particles is absent from the literature and there are no standardized methodologies currently available for evaluation. Thus, the purpose of this study was to examine the ecological services of tree belts for air quality by decreasing atmospheric pesticide dispersal. Our hypothesis was that the use of tree belts as windbreaks will reduce suspended dust particles carrying pesticides from agricultural fields and plantations, which will accumulate both on the trees and on the ground below to reduce pesticide leakage from agricultural areas to nearby natural and inhabited areas.

\section{Materials and Methods}

\subsection{Study Area}

Four study sites were selected in the northern Negev desert edge: Asaf, Dorot, Shmarya and Lachish, all near agriculture and intensive field crops or plantations (Figure 1, Table 1). In this area the average annual precipitation is $300-450 \mathrm{~mm}$ mainly between November and March. The minimum temperature is $6-8{ }^{\circ} \mathrm{C}$ in the winter (January-February) and $32-34{ }^{\circ} \mathrm{C}$ in the summer (July-August). The study sites were chosen according to the prevailing western winds (Figure 1). As such, the cultivated field is exposed to the wind and the tree belt is nearby. The windbreaks were located around a variety of field crops and plantations, including: potato, carrot, peanuts, wheat and barley, vineyards, orchards and almonds (Table 1).

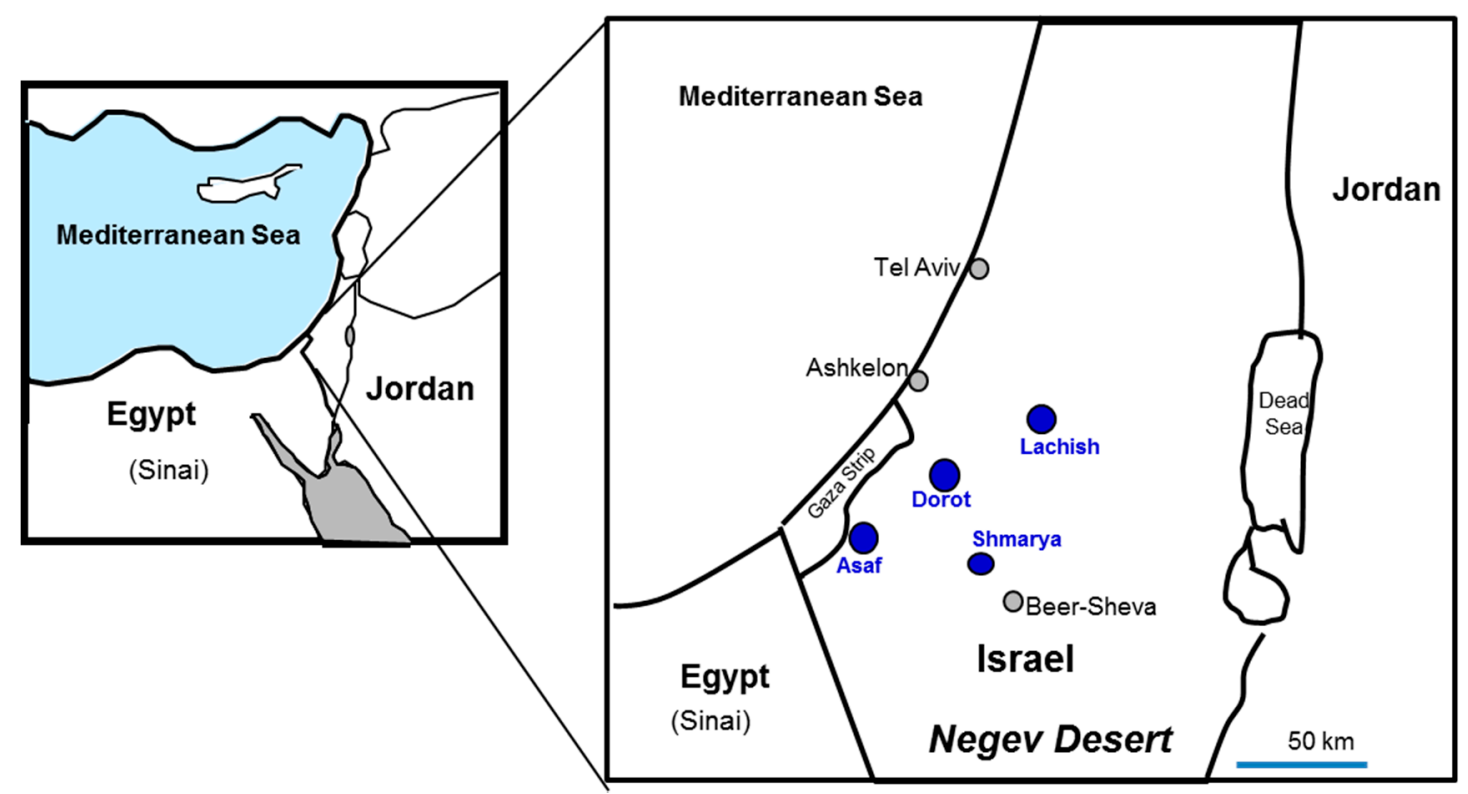

Figure 1. The location of the study sites in the northern Negev semi-arid region with annual average rainfall: Lachish (400 mm), Dorot (300 mm), Shmarya (230 mm) and Asaf (250 mm). 
Table 1. Description of the study sites.

\begin{tabular}{|c|c|c|c|c|c|c|}
\hline Site & $\begin{array}{c}\text { Location } \\
\text { (Longitude, } \\
\text { Latitude) }\end{array}$ & $\begin{array}{c}\text { Soil Textural Class } \\
\text { [USDA Textural } \\
\text { Classes] }\end{array}$ & $\begin{array}{c}\text { Soil } \\
\text { Granulometry }\end{array}$ & Crops & Tree Species & Tree Data \\
\hline Assaf & $\begin{array}{c}31^{\circ} 20^{\prime} 59^{\prime \prime} \mathrm{N} \\
34^{\circ} 26^{\prime} 3^{\prime \prime} \mathrm{E}\end{array}$ & Sandy clay loam & \multirow{2}{*}{$\begin{array}{l}23.8 \% \text { clay, } \\
67.5 \% \text { sand, } \\
8.8 \% \text { silt }\end{array}$} & $\begin{array}{l}\text { Peanuts, potatoes, } \\
\text { carrots }\end{array}$ & $\begin{array}{c}\text { Pinus } \\
\text { halepensis }\end{array}$ & $\begin{array}{l}\text { 10-15 } \mathrm{m} \text { high and } \\
8-10 \mathrm{~m} \text { wide }\end{array}$ \\
\hline Dorot & $\begin{array}{l}31^{\circ} 30^{\prime} 35^{\prime \prime} \mathrm{N} \\
34^{\circ} 39^{\prime} 24^{\prime \prime} \mathrm{E}\end{array}$ & Sandy clay loam & & Wheat, potatoes & $\begin{array}{c}\text { Eucalyptus } \\
\text { camaldulensis }\end{array}$ & \multirow{2}{*}{$\begin{array}{l}\text { 15-20 } \mathrm{m} \text { high and } \\
5-7 \mathrm{~m} \text { wide }\end{array}$} \\
\hline Shmarya & $\begin{array}{l}31^{\circ} 20^{\prime} 31^{\prime \prime} \mathrm{N} \\
34^{\circ} 37^{\prime} 47.5^{\prime \prime} \mathrm{E}\end{array}$ & Sandy clay & \multirow{2}{*}{$\begin{array}{c}49.2 \% \text { clay, } \\
37.5 \% \text { sand, } \\
13.3 \% \text { silt }\end{array}$} & $\begin{array}{c}\text { Wheat, barley and } \\
\text { potatoes }\end{array}$ & $\begin{array}{c}\text { Eucalyptus } \\
\text { camaldulensis }\end{array}$ & \\
\hline Lachish & $\begin{array}{l}31^{\circ} 33^{\prime} 57.4^{\prime \prime} \mathrm{N} \\
34^{\circ} 49^{\prime} 30.2^{\prime \prime} \mathrm{E}\end{array}$ & Sandy clay & & $\begin{array}{l}\text { Almond groves, } \\
\text { orchards, vineyards }\end{array}$ & $\begin{array}{l}\text { Ceratonia } \\
\text { siliqua }\end{array}$ & $\begin{array}{l}10-15 \mathrm{~m} \text { high and } \\
10-15 \mathrm{~m} \text { wide }\end{array}$ \\
\hline
\end{tabular}

\subsection{Data Collection}

The study was conducted during 2013-2015. As a first step, the seasonal dependence of the wind direction was examined (Israel Meteorological Service data) [34]. In most of the seasons the dominant winds in the region are in the western sector (from northwest to southwest) (Appendix A, Figure A1). During the first two years, tree belts of Eucalyptus camaldulensis were examined at Shmarya, Asaf and Dorot; in the third year Pinus halepensis (pine) and Ceratonia siliqua (carob) tree belts were examined at Asaf and Lachish (see Table 1 for tree dimensions). Samples were collected monthly (for 36 months), throughout the study period and seasonal dependence was examined at each site, with respect to periods of agricultural activity (plowing, sowing, harvesting treatments in the growing stages, vintage).

Dust accumulation was measured using passive aeolian dust collectors that consist of a plastic pan $(47 \times 31 \times 10 \mathrm{~cm})[35,36]$ with two layers of spherical glass marbles $(17 \mathrm{~mm}$ diameter). These collectors were set in parallel to the wind direction with a distance of 1-2 $\mathrm{m}$ between collectors at three locations ( 5 replicates in each); beneath the first tree line (hereafter location 1 ), beneath the fifth line of trees at the edge of the field (hereafter location 2), and in the center of the cultivated field (Figure 1). The collectors protruded $5 \mathrm{~cm}$ above the soil surface to avoid dust input directly by the soil around the collector. Dust particles accumulating in the collectors were removed from the collectors on a monthly basis by brushing the marbles and the pans. The accumulated dust was weighed, and the samples were analyzed for pesticides. The collected dust samples were analyzed for granulometry, chemistry, qualitative and quantitative pesticides, according to distances from the fields of intensive farming.

\subsection{Aeolian Particle Analysis}

Particle size distribution (PSD) was analyzed by the laser diffractometer technique (ANALYSETTE 22 MicroTec Plus, FRITSCH, Idar-Oberstein, Germany) which measures particles in the size range of $0.08-2000 \mathrm{~mm}$. The preparation of each sample included splitting samples by a mechanical device and removal of distinct organic matter. Samples were dispersed in a sodium hexametaphosphate solution $(0.5 \%)$ by sonication $(38 \mathrm{kHz})$. Particle size distribution data were calculated using the Fraunhofer model and MaS control software (FRITSCH GmbH, Idar-Oberstein, Germany, version 1.8) [37]. The laboratory of Katif Research Center, Sdot-Negev, for the identification and extraction of pesticides in which we performed the dust analysis for the extraction of pesticides is approved by the Israeli Authority of Laboratory Accreditation and by the relevant European Community Authorities for analysis of agricultural chemical residues according to European standard ISO/IEC 17025. The identification and quantification of pesticides in the dust were carried out by gas chromatography-mass spectrometry (GC-MS) (Agilent 5975, Agilent Technologies, Inc., Santa Clara, CA, USA), and Liquid chromatography-mass spectrometry (LC-MS) (Micromass Quarto-Ultima, Almere, The Netherlands). These devices are able to detect the presence of many different pesticides licensed in Israel, with an accuracy of up to $1 \mathrm{ppb}$. The LC-MS/MS analysis was performed according to Martel and Lair [38], after extraction with acetonitrile and hexane at a ratio of 1:1. The GC-MS analysis was performed according 
to the conventional method for assessing residual pesticides by multiple reaction monitoring [39]. Standard organophosphate (OP) solutions was prepared at $1 \mathrm{mg} / \mathrm{mL}$ of each relevant analyte in acetone using neat materials ( $>98 \%$ purity) [40]. Further dilutions were made in hexane to prepare OP calibrant solutions. One $\mathrm{ng} / \mathrm{mL}$ of tributylphosphate was used as an internal standard for gas chromatography in all samples. Identification and quantification of the target OP were done by GC/mass selective detection (MSD) in selected ion monitoring mode using an Agilant GC 6890 series (Agilent Technologies, Inc. Wilmington, DE, USA), equipped with a 5973 mass selective detector and a $30 \mathrm{~m}$ by $0.25 \mathrm{~mm}$ id. J\&W capillary column (Agilent Technologies, Inc.) with a $0.25 \mu \mathrm{m} \mathrm{df}$ bonded phase. In addition, dust samples were tested for their morphology using a scanning electron microscope with energy dispersive spectroscopy (SEM-EDS, Quanta 200, FEI, ThermoFisher Scientific, Hillsboro, OR, USA).

To study the possibility that dust-carried pesticides are washed by rainfall from the tree leaves to the ground below, $100 \mathrm{~g}$ soil in two locations at Lachish-beneath the tree belt of $\mathrm{C}$. siliqua (carob)-were analyzed for the presence of pesticides in four horizons: A, the top layer of organic material; B, a delicate layer of organic material on the soil surface; $C$, the topsoil, $0-1 \mathrm{~cm}$ depth; $D$, the bottom ground layer, $2-3 \mathrm{~cm}$ depth.

\subsection{Statistics}

Correlation was conducted between the amount of pesticide per month and the amount of dust per month. The amount of accumulated aeolian dust particles was compared between the four study sites in the northern Negev. The samples were collected monthly, for 36 months. Each site had 3 locations; center of cultivated field; beneath the first row of the tree belt; and beneath the fifth row of the tree belt. In each location five collectors were placed. The dust accumulating in the collectors was analyzed seasonally for each location within each site, $(N=15)$, and between sites, using; ANOVA and Tukey HSD post hoc tests (for all tests $p<0.05$ ) in JMP®(version 13, SAS, Cary, NC, USA) (https://www.jmp.com).

\section{Results}

The average monthly amount of dust collected decreased in the order Shmarya $\left(22.06 \mathrm{~g} \mathrm{~m}^{-2}\right)>$ Asaf $\left(15.94 \mathrm{~g} \mathrm{~m}^{-2}\right)>\operatorname{Dorot}\left(4.90 \mathrm{~g} \mathrm{~m}^{-2}\right)$ (Figure 2). No significant statistical differences were found between the location of the aeolian dust collectors (the center of the field, beneath the first row of trees, and beneath the fifth row of trees) (data not shown). At Shmarya, the highest amount was found in the summer and the lowest amount in the winter. At Asaf, the highest amount was found in the winter, although it was not significantly different from the amounts found in the other seasons. The lowest amount of aeolian dust was obtained at Dorot (Figure 2).

No significant differences were found in particle size distribution of the samples from the four study sites, Asaf, Shmarya, Dorot, and Lachish (Table 2). The maximum particle size was $100 \mu \mathrm{m}$, with PM1 (less than $1 \mu \mathrm{m}$ in diameter) $=4.9 \%$, PM2.5 $=13.17 \%$, PM10 $=32.03 \%$ and PM20 $=49.0 \%$ (Table 2 ) (Appendix A, Figure A2). 


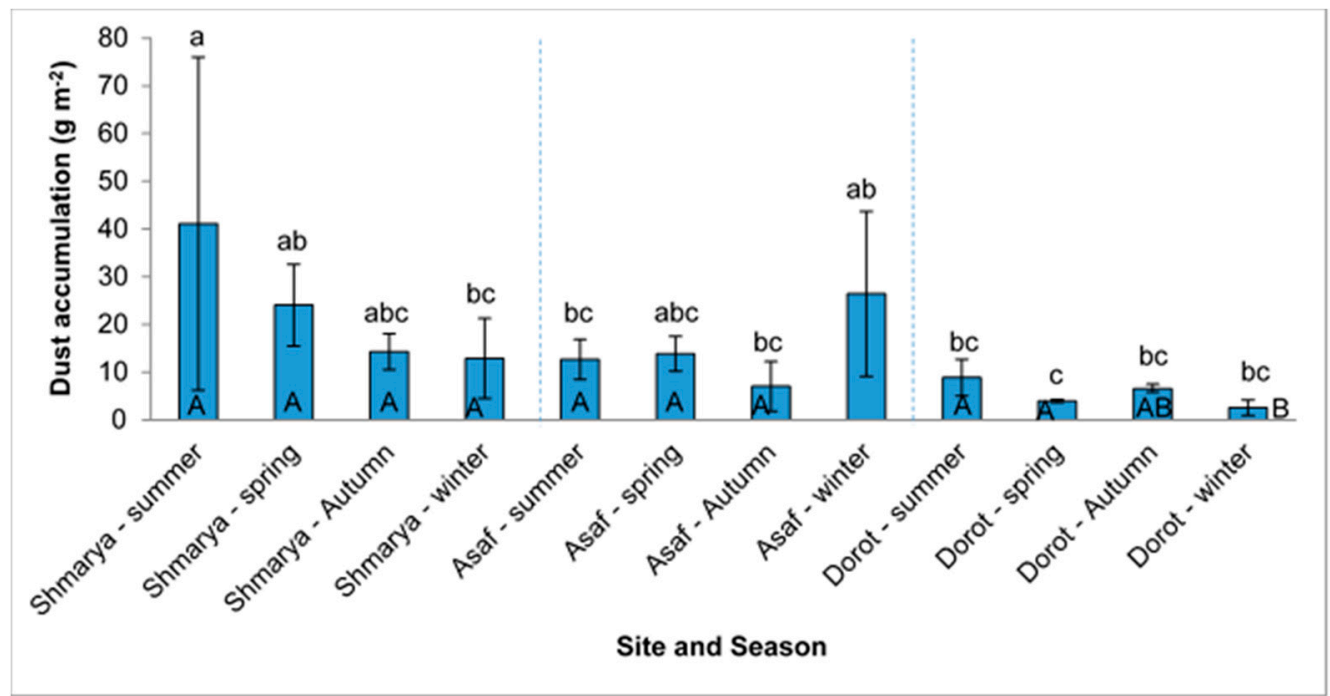

Figure 2. Accumulation of dust in collectors, at each of the three sites, by season (mean $\pm \mathrm{SE}$, different letters indicate statistical differences, according to Tukey's range test, $p<0.05$ ). The letters above the columns indicate statistical differences between all seasons, and sites and the capital letters indicate statistical differences between the seasons within each site.

Table 2. Grain-size distribution of the aeolian dust particles with a High-Resolution Laser Diffractometer, (USDA classification of sand sizes for clay, silt, sand) and atmospheric particulate matter (PM) of samples collected at the four sites. 1-3 Shmarya, 4-6 Asaf, 7-9 Dorot and 10-12 Lachish. One sample for each year of the study.

\begin{tabular}{ccccccccccccc}
\hline Sample & $\mathbf{1}$ & $\mathbf{2}$ & $\mathbf{3}$ & $\mathbf{4}$ & $\mathbf{5}$ & $\mathbf{6}$ & $\mathbf{7}$ & $\mathbf{8}$ & $\mathbf{9}$ & $\mathbf{1 0}$ & $\mathbf{1 1}$ & $\mathbf{1 2}$ \\
\hline & \multicolumn{8}{c}{ A. Parameters $(\%)$} \\
\hline Clay $(<2 \mu \mathrm{m})$ & 11.72 & 11.86 & 9.07 & 11.47 & 10.59 & 10.87 & 8.76 & 11.51 & 12.20 & 12.06 & 8.46 & 11.26 \\
Silt $(2-63 \mu \mathrm{m})$ & 83.22 & 81.27 & 83.68 & 81.59 & 80.01 & 79.91 & 80.13 & 80.80 & 80.92 & 80.98 & 77.89 & 80.07 \\
Sand $(>63 \mu \mathrm{m})$ & 5.06 & 6.87 & 7.25 & 6.94 & 9.38 & 9.22 & 11.11 & 7.68 & 6.88 & 6.96 & 13.65 & 8.66 \\
\hline \multicolumn{10}{c}{ B. Size fractions $(\%)$} \\
\hline PM20 & 49.00 & 47.60 & 47.88 & 48.97 & 41.97 & 42.74 & 38.69 & 43.35 & 47.59 & 45.35 & 37.64 & 43.23 \\
PM10 & 35.14 & 34.51 & 32.64 & 35.08 & 31.06 & 30.95 & 27.29 & 31.32 & 35.00 & 33.13 & 26.42 & 31.79 \\
PM2.5 & 14.39 & 14.49 & 11.32 & 14.10 & 12.94 & 13.19 & 10.68 & 13.80 & 14.77 & 14.50 & 10.28 & 13.57 \\
PM $\leq 1.0$ & 5.05 & 5.23 & 3.76 & 4.91 & 4.77 & 4.98 & 3.98 & 5.53 & 5.65 & 5.77 & 3.88 & 5.32 \\
\hline
\end{tabular}

Eighteen pesticides were found in agricultural field crops and plantations and in the adjacent planted tree belts during the three years of the study, including; herbicides (against broad-leaved plants and cereals) insecticides and fungicides (for control of mildew and mold) (Table 3). The pesticides were from various groups; organophosphate, organochlorine, substituted urea, carbamate, Pyrimidine, strobin, pyrethroid, phenoxy, triazolinone, phenylaniline, thiophtalimide, benzoylurea, diphenyl ether and azole. 
Table 3. Major pesticides found in agricultural fields and adjacent planted forests during the three years of the study and their applications in agriculture.

\begin{tabular}{ccc}
\hline Pesticide & Group & Application \\
\hline Bifenthrin & Pyrethroid & Insecticide against pests of cotton, vegetables and flowers \\
Carfentrazone-ethyl & Triazolinone & Herbicide against broad-leaved weeds in cereal crops \\
Chlorpyrifos & Organophosphate & Insecticide for vegetables, orchards and vineyards \\
Chlorthal-dimethyl- & Chloro-benzen & Pre-emergence herbicide for grass and common weeds \\
Chlorothalonil & Organochlorine & Insecticide against mites for citrus orchards, field crops, vegetable \\
Cyprodinil & Pyrimidine & and flowers \\
Diazinon & Organophosphate & Insecticide against pests of field crops, orchards and flowers \\
Diflufenican & Phenoxy & Herbicide applied in orchards and vineyards \\
Diphenylamine & Phenylaniline & Fungicide for citrus and other orchards \\
Diuron & Substituted Urea & Herbicide for orchards and field crops \\
Endosulfan & Organochlorine & Insecticide against pests in deciduous orchards \\
Folpet & Thiophtalimide & Fungicide for control of mildew in vineyards and field crops \\
Novaluron & Benzoylurea & Insecticide for cotton and potatoes \\
Oxyfluorfen & Diphenyl Ether & General herbicide for orchards, flowers and field crops \\
Penconazole & Azole & Fungicide for orchards, vegetables and flowers \\
Pirimicarb & Carbamate & Insecticide for vegetables and field crops \\
Pyrimethanil & Pyrimidine & Mold fungicide for vineyards, flowers and field crops \\
Trifloxystrobin & Strobin & Fungicide for mildew in orchards and vegetables \\
\hline
\end{tabular}

Not all the aeolian dust samples were found to contained pesticides (Tables A1 and A2). Furthermore, in a few cases different types of pesticides were found in the same collector at the same time. A low correlation $\left(r^{2}=0.2246, p<0.05\right)$ was found between the amount of pesticide per month $\left(\mu \mathrm{g} \mathrm{m}^{-2}\right)$ and the amount of dust per month $\left(\mathrm{g} \mathrm{m}^{-2}\right)$ (Appendix A, Figure A3).

Table 4 shows the types of pesticides that were found in Lachish site (December 2014 and August 2015) in the field and beneath C. siliqua and P. halepensis. Bifentherin, oxyfluorfen and trifloxystrobi were found in the field during the winter, spring and summer seasons, while in summer season bifentherin and diphenylamine were found beneath the first tree belt of $C$. siliqua. The highest amount of pesticide found was of oxyfluorfen $\left(240.93 \mu \mathrm{g} \mathrm{m}{ }^{2}\right)$, used as ageneral herbicide for orchards, flowers and field crops.

Table 4. Types of pesticides that were found at Lachish between December 2014 and August 2015. Center of cultivated field [Field]; Beneath the first row of the tree belt (1). Data are monthly averages for the seasons: winter (December 2014-February 2015); spring (March-May 2015) and summer (June-August 2015). No pesticides were found at Asaf during this period. The table presents only the periods during which pesticides were found.

\begin{tabular}{|c|c|c|c|c|}
\hline Site and Season & Location & $\begin{array}{l}\text { Monthly Aeolian } \\
\text { Dust Particle } \\
\text { Accumulation } \\
\left(\mathrm{g} \mathrm{m}^{-2}\right)\end{array}$ & Pesticide & $\begin{array}{c}\text { Pesticide per } \\
\text { Month }\left(\mu \mathrm{g} \mathrm{m}^{-2}\right)\end{array}$ \\
\hline Lachish/winter & Field near C. siliqua & 55.4 & Bifenthrin & 1.57 \\
\hline Lachish/spring & Field near $C$. siliqua & 58.2 & Oxyfluorfen & 240.93 \\
\hline Lachish/spring & Field near $C$. siliqua & 58.2 & Trifloxystrobin & 8.34 \\
\hline Lachish/summer & Field near $C$. siliqua & 22.3 & Bifenthrin & 3.98 \\
\hline Lachish/summer & $\begin{array}{l}\text { Field near } P \text {. } \\
\text { halepensis }\end{array}$ & 8 & Bifenthrin & 9.6 \\
\hline Lachish/summer & 1-near C. siliqua & 8.2 & Bifenthrin & 0.73 \\
\hline Lachish/summer & 1-near C. siliqua & 8.2 & Diphenylamine & 2.3 \\
\hline Lachish/summer & $\begin{array}{c}\text { Field near } P \text {. } \\
\text { halepensis }\end{array}$ & 8 & Folpet & 16.21 \\
\hline
\end{tabular}


Analysis of the soil samples of four horizons beneath the tree belts at Lachish showed that no pesticides were found beneath the pines. Nevertheless, the presence of pesticides beneath the $C$. siliqua tree belts revealed that pesticides do accumulate in the soil beneath the trees (Table 4). The highest concentration per month was of bifenthrin $\left(29.8-255.1 \mu \mathrm{g} \mathrm{kg}\right.$ soil $\left.{ }^{-1}\right)$ in horizons B, C and D beneath the tree belt, and pyrimethanil $\left(240.13 \mu \mathrm{g} \mathrm{kg} \mathrm{soil}{ }^{-1}\right)$ in horizon D in the agricultural field. diphenylamine and diflufenican were detected beneath the tree belt in Horizons A and B, respectively (Table 5).

Table 5. Pesticides found in the soil layers at Lachish beneath C. siliqua (on 07/01/2015). Center of cultivated field [Field]; Beneath the first row of trees (1); Beneath the fifth row of trees (2).

\begin{tabular}{ccccc}
\hline Site & Location & Horizon & Pesticide & $\begin{array}{c}\text { Amount of Pesticide } \\
(\boldsymbol{\mu g ~ k g ~ s o i l - 1 )}\end{array}$ \\
\hline Lachish & Field & D & Pyrimethanil & 240.13 \\
Lachish & 1 & A & Diphenylamine & 20.63 \\
Lachish & 1 & B & Bifenthrin & 29.78 \\
Lachish & 1 & D & Bifenthrin & 30.34 \\
Lachish & 2 & B & Diflufenican & 88.54 \\
Lachish & 2 & B & Bifenthrin & 31.5 \\
Lachish & 2 & C & Bifenthrin & 255.1 \\
\hline
\end{tabular}

${ }^{*} \mathrm{~A}=$ the top layer of organic material; $\mathrm{B}=$ delicate layer of organic material on the soil surface; $\mathrm{C}=$ topsoil, $0-1 \mathrm{~cm}$ depth; $\mathrm{D}=$ bottom ground layer, $2-3 \mathrm{~cm}$ depth.

\section{Discussion}

The results allow estimation of aeolian dust deposition at the field scale in the northern Negev region, originating in agricultural activity and regional dust storms. They also provide evidence of the role of aeolian dust particles in atmospheric transport of pesticides and the associated importance of planting tree belts. The aeolian dust amounts, characteristic of agricultural activity, are significantly higher than the amounts that occur in natural dust storms, particularly in arid regions [36] (Figure 2). The summer months (June, July, and August) are characterized by low agricultural activity (except for the late harvest). The next two months, September and October, when the fields undergo preparatory processing for the rainy winter season, are expected to have an increase in dust amount. However, no clear pattern in the quantities of dust between seasons was found. Even though dust emission in the agricultural field can be vary between seasons due to wind speeds and/or soil conditions, the filtering capacity of the tree belts is limited. A significant proportion of the aeolian dust is of a particle size that allows long-distance travel through the atmosphere under all conditions of (northwestern) winds of the northern Negev (Appendix A, Figure A1). Larger soil particles or aggregates move close to the surface in the form of saltation and are mostly found in adjacent areas [41]. The aggregates formed by small dust particles may break down during their movement to release additional suspended PM into the atmosphere [42].

Our study revealed that the planted tree belts are of great importance in reducing the quantities of aeolian dust particles and consequently in lowering the distribution of transported pesticides. In the first two years of the study, high amounts of pesticides originating from the agricultural fields were found beneath the first and even fifth rows of the tree (E. camaldulensis) belts during the winter and spring seasons.

Pesticides in the accumulated aeolian dust particles were found only during some seasons. In the autumn, pesticides were not found in the three sites, even when examined in consecutive years (Shmarya, Autumn 2013, and 2014) (Appendix A, Tables A1 and A2). It can be assumed that this season is usually used to prepare the lands for sowing and thus most of the crops in the agricultural areas are absent. During the winter, spring and summer seasons, the pesticides accompany crop growth and therefore they are detected in the dust. At Asaf, treatments in citrus fields and orchards were applied in the winter against insects and mites (such as diphenylamine, endosulfan) and against fungi (carfentrazone-ethyl and chlorothalonil). At Shmarya, the three insecticides and fungicide were also 
used in the citrus fields and plantations, in addition to herbicides (diuron, carfentrazone-ethyl). At Dorot, insecticides against mites (diazinon, chlorthal-dimethyl, endosulfan, novaluron, bifenthrin) are used in field crops and orchards as well as herbicides (diuron) (Appendix A, Tables A1 and A2).

In the third year of the study, the aeolian dust collectors were moved to new sampling locations at Asaf and Lachish. At Asaf, they were located within a wheat field and beneath tree belts of P. halepensis (pine). At Lachish they were located within a grape vineyard and in citrus and almond plantations and beneath $C$. siliqua (carob) tree belts. We wanted to determine whether the pines and the carob tree belts play a similar role to that of the eucalyptus tree belts. The results showed that the use of pesticides in almond groves and vineyards is more focused and seasonal. At Asaf, a correlation was found between pesticide types originating in the field and those beneath the tree belts (Appendix A, Table A1). However, pesticides found in the field did not always match those found beneath the tree belts (Appendix A, Tables A1 and A2 and Table 4). Diphenylamine, a fungicidal herbicide in orchards and citrus orchards, was found in the spring at Lachish in the collectors beneath the fifth row of $C$. siliqua trees. Its presence can be explained by local use or by transport from a distal source to the orchard plantations. During the summer at Lachish, C. siliqua played a role in filtering the insecticide bifenthrin, which is used as an insecticide in cotton, vegetables and flowers, and diphenylamine, which appears to be active in the nearby almond grove (Table 4).

Tests for the presence of pesticides were conducted in the soil, both in the agricultural field and in sampling points 1 and 2 beneath the tree belts at Lachish. In the soil, pesticides are exposed to decomposition by a large variety of microorganisms and therefore were unlikely to be detected or found in low concentrations unless they were only recently applied $[15,43,44]$. It is interesting to note that while no traces of pesticides were found in the field and beneath the pine trees, herbicide residues were found near and beneath $C$. siliqua trees situated near the vineyards (Table 5). Residues of diflufenican, diphenylamine, pyrimethanil and bifenthrin were found both in the field and beneath $C$. siliqua. The first was used as an herbicide applied in orchards and vineyards, the second and the third are fungicides to control fungi and molds and the fourth is used as an insecticide.

\section{Conclusions}

The present study highlights the importance of planting trees as green belts on the margins of agricultural fields in the northern and western Negev. This relates not only to the efficiency of preventing aeolian dust from agricultural activity, which is a significant source of air pollution during natural storms, but also to reducing the air leakage of pesticides to natural and populated areas. The types of trees common in planting in the northern Negev region are eucalyptus, pine and carob trees. Despite differences in the shape of the canopy and the age of the different types of planted trees, there was no significant difference in the size of the aeolian dust particles. All types of planted trees allow efficient reduction of suspended particles of long-distance travel $(<20 \mu \mathrm{m}$ in diameter), thus contributing to reduced air pollution. Eighteen various pesticides, insecticides, fungicides and herbicides were found in the present study, both in the fields and beneath the first and fifth rows of the tree belts. This indicates an important function of the trees, which has not been included so far in planting and afforestation policies. Seasonality is important because pesticide use usually corresponds to the agricultural activities typical of field crops, orchards and vineyards. Damage to natural systems adjacent to intensive agricultural field, may be temporary and/or cumulative and harms all stages of the food web. This study provides an opportunity for further research on topics such as atmospheric dispersion of dust from agricultural field sources into nearby environments and risks to human health from dust exposure.

Author Contributions: S.S. (Shimshon Shuker) and Y.K. helped with collecting the field data. I.K. performed the aeolian dust particle analysis. S.S. (Sarig Shlomo) was responsible for the pesticide analysis. E.Z. was the project leader and wrote the manuscript. All authors reviewed and approved the final version.

Funding: The study was supported by a grant from the Forestry Department of the Jewish National Fund (JNF). 
Acknowledgments: The authors would like to thank Itzhak Moshe, Gil Siaki and Yahel Porat for their administrative support. We thank Daniel Barkai for his help in the field.

Conflicts of Interest: The authors declare no conflicts of interest.

\section{Appendix A}

Supplementary materials for the types of pesticides found at the three research sites, the commonness of wind directions for the Northern Negev, the particle size distribution and the Correlation between the amount of pesticide per month and the amount of dust per month.

Table A1. Types of pesticides found at the three research sites between September 2013 and May 2014; Center of cultivated field (field); Beneath the first E. camaldulensis row (1); Beneath the fifth row of trees (2). Data are monthly averages for the season: autumn (September-November 2013), winter (December 2013-February 2014) and spring (March-May 2014). Sites that appear twice indicate different types of pesticides found in the same collector.

\begin{tabular}{|c|c|c|c|c|}
\hline Site and Season & Location & $\begin{array}{c}\text { Average Amount } \\
\text { of Dust per Month } \\
\left(\mathrm{g} \mathrm{m}^{-2}\right)\end{array}$ & Pesticide & $\begin{array}{c}\text { Amount of } \\
\text { Pesticide per } \\
\text { Month }\left(\mu \mathrm{g} \mathrm{m}^{-2}\right)\end{array}$ \\
\hline Asaf/Autumn & Field & 1.8 & $\mathrm{ND}^{*}$ & ND \\
\hline Asaf/Autumn & 1 & 12.2 & ND & ND \\
\hline Asaf/Autumn & 2 & 7.1 & ND & ND \\
\hline Asaf/Autumn & Field & 48.2 & Chlorothalonil & 0.293 \\
\hline Asaf/Autumn & 1 & 8.7 & Diphenylamine & 0.021 \\
\hline Asaf/Winter & 1 & 8.7 & Chlorothalonil & 0.072 \\
\hline Asaf/Winter & 2 & 33.2 & Chlorothalonil & 4.417 \\
\hline Asaf/Winter & 2 & 33.2 & Endosulfan & 1.174 \\
\hline Asaf/Spring & Field & 16.4 & Chlorothalonil & 0.045 \\
\hline Asaf/Spring & 1 & 9.7 & Endosulfan & 0.064 \\
\hline Asaf/Spring & 2 & 15.5 & Chlorothalonil & 0.465 \\
\hline Dorot/Autumn & Field & 7.7 & ND & ND \\
\hline Dorot/Autumn & 1 & 6 & ND & ND \\
\hline Dorot/Autumn & 2 & 7.2 & ND & ND \\
\hline Dorot/Winter & Field & 3.8 & Diazinon & 0.023 \\
\hline Dorot/Winter & Field & 3.8 & Chlorthal-dimethyl & 0.004 \\
\hline Dorot/Winter & 1 & 2.3 & Endosulfan & 0.388 \\
\hline Dorot/Winter & 2 & 0.3 & ND & ND \\
\hline
\end{tabular}

Table A2. Types of pesticides found at the three research sites between September 2014 and May 2015; Center of cultivated field (field); Beneath the first E. camaldulensis row (1); Beneath the fifth row of trees (2). Data are monthly averages for the season: autumn (September-November 2014), winter (December 2014-February 2015) and spring (March-May 2015). Sites that appear twice indicate different types of pesticides found in the same collector.

\begin{tabular}{|c|c|c|c|c|}
\hline Site and Season & Location & $\begin{array}{l}\text { Average Amount } \\
\text { of Dust per Month } \\
\left(\mathrm{g} \mathrm{m}^{-2}\right)\end{array}$ & Pesticide & $\begin{array}{c}\text { Amount of } \\
\text { Pesticide per } \\
\text { Month }\left(\mu \mathrm{g} \mathrm{m}^{-2}\right)\end{array}$ \\
\hline Dorot/Spring & Field & 4.2 & Bifenthrin & 0.017 \\
\hline Dorot/Spring & Field & 4.2 & Diuron & 0.023 \\
\hline Dorot/Spring & 1 & 3.6 & Novaluron & 0.027 \\
\hline Dorot/Spring & 1 & 3.6 & Diuron & 0.008 \\
\hline Dorot/Spring & 1 & 3.6 & Chlorothalonil & 0.26 \\
\hline Dorot/Spring & 1 & 3.6 & Endosulfan & 0.053 \\
\hline Dorot/Spring & 2 & 4.2 & Novaluron & 0.014 \\
\hline
\end{tabular}


Table A2. Cont.

\begin{tabular}{|c|c|c|c|c|}
\hline Site and Season & Location & $\begin{array}{c}\text { Average Amount } \\
\text { of Dust per Month } \\
\left(\mathrm{g} \mathrm{m}^{-2}\right)\end{array}$ & Pesticide & $\begin{array}{c}\text { Amount of } \\
\text { Pesticide per } \\
\text { Month }\left(\mu \mathrm{g} \mathrm{m}^{-2}\right)\end{array}$ \\
\hline Dorot/Spring & 2 & 4.2 & Diuron & 0.019 \\
\hline Dorot/Spring & 2 & 4.2 & Chlorothalonil & 0.465 \\
\hline Shmarya/Autumn & Field & 10.3 & $\mathrm{ND}^{*}$ & ND \\
\hline Shmarya/Autumn & 1 & 14.9 & ND & ND \\
\hline Shmarya/Autumn & 2 & 17.7 & ND & ND \\
\hline Shmarya/Winter & Field & 26.8 & Diuron & 0.03 \\
\hline Shmarya/Winter & 1 & 4 & ND & ND \\
\hline Shmarya/Winter & 2 & 11.2 & Chlorthal-dimethyl & 0.085 \\
\hline Shmarya/Winter & 2 & 11.2 & Diuron & 0.066 \\
\hline Shmarya/Winter & 2 & 11.2 & Chlorothalonil & 0.294 \\
\hline Shmarya/Spring & Field & 7.3 & ND & ND \\
\hline Shmarya/Spring & 1 & 30.4 & Chlorothalonil & 0.584 \\
\hline Shmarya/Spring & 1 & 30.4 & Diuron & 0.034 \\
\hline Shmarya/Spring & 2 & 25.4 & Diuron & 0.041 \\
\hline Shmarya/Spring & 2 & 25.4 & Chlorothalonil & 1.805 \\
\hline Shmarya/Spring & 2 & 25.4 & Endosulfan & 2.297 \\
\hline
\end{tabular}

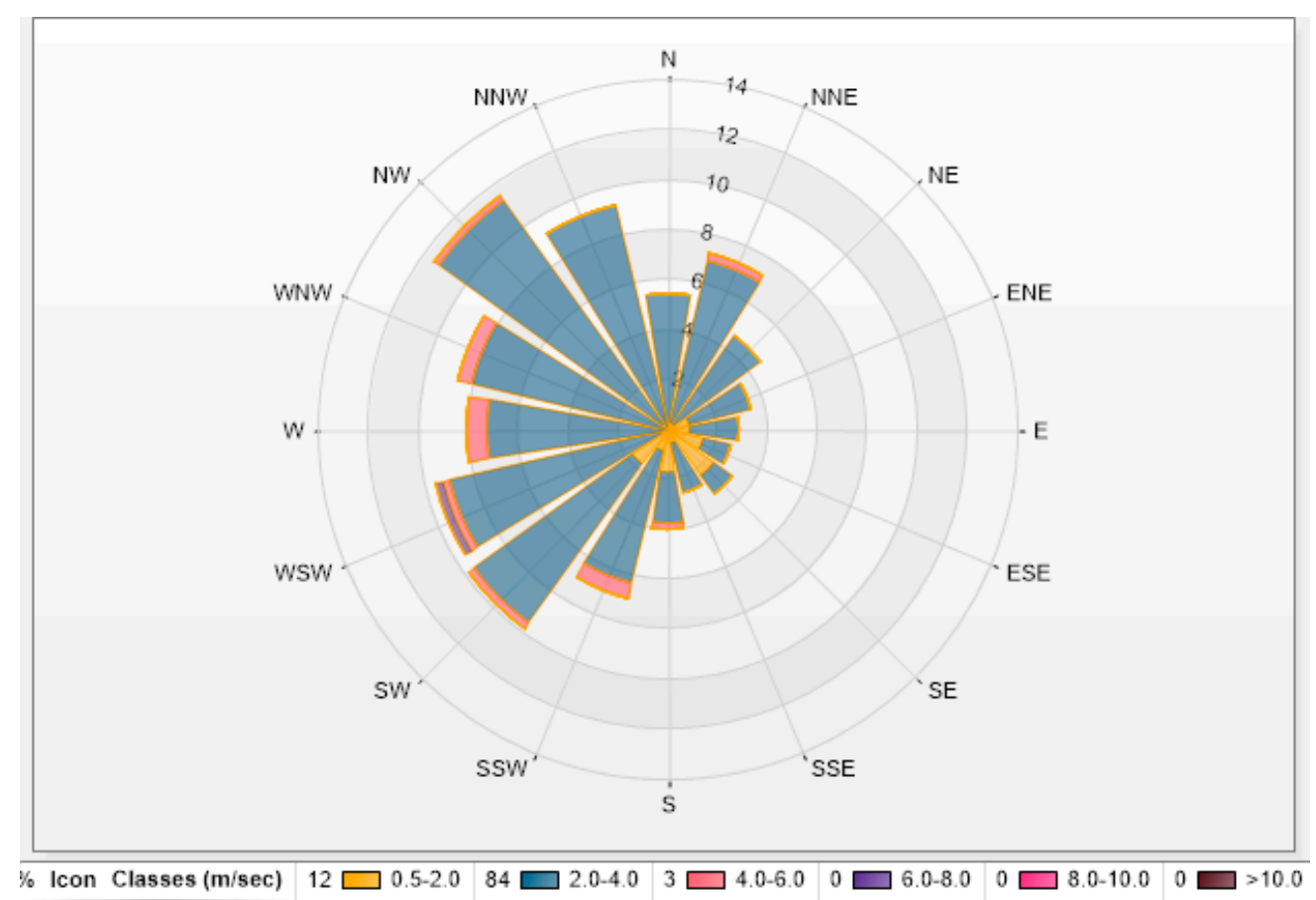

Figure A1. Compass card of the commonness of wind directions for the Northern Negev [34]. 


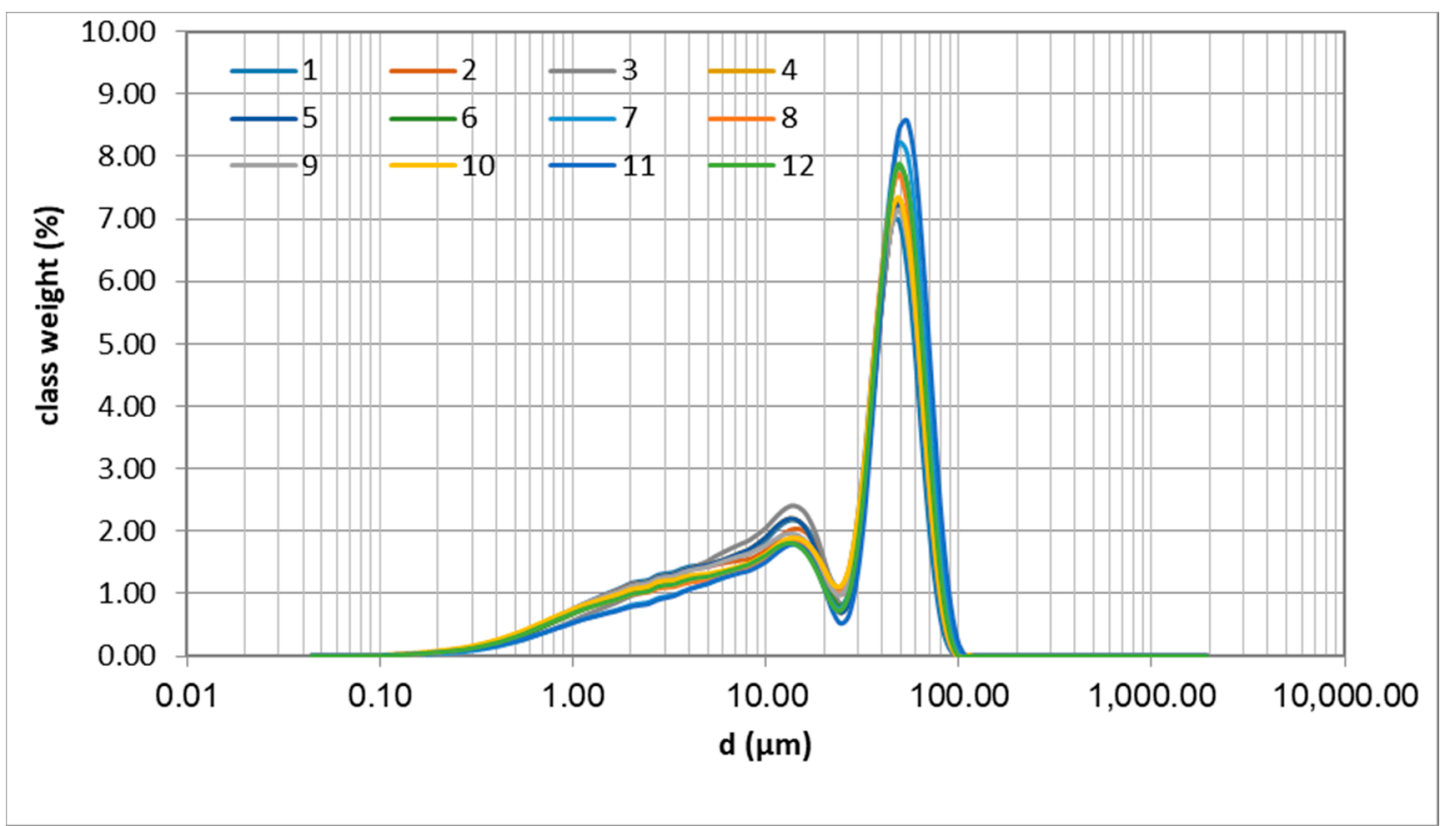

Figure A2. Particle size distribution (PSD) was analyzed by the laser diffractometer technique (ANALYSETTE 22 MicroTec Plus). Twelve aeolian samples were tested from all sites, one sample for each year of the study. 1-3 Shmarya, 4-6 Asaf, 7-9 Dorot and 10-12 Lachish.

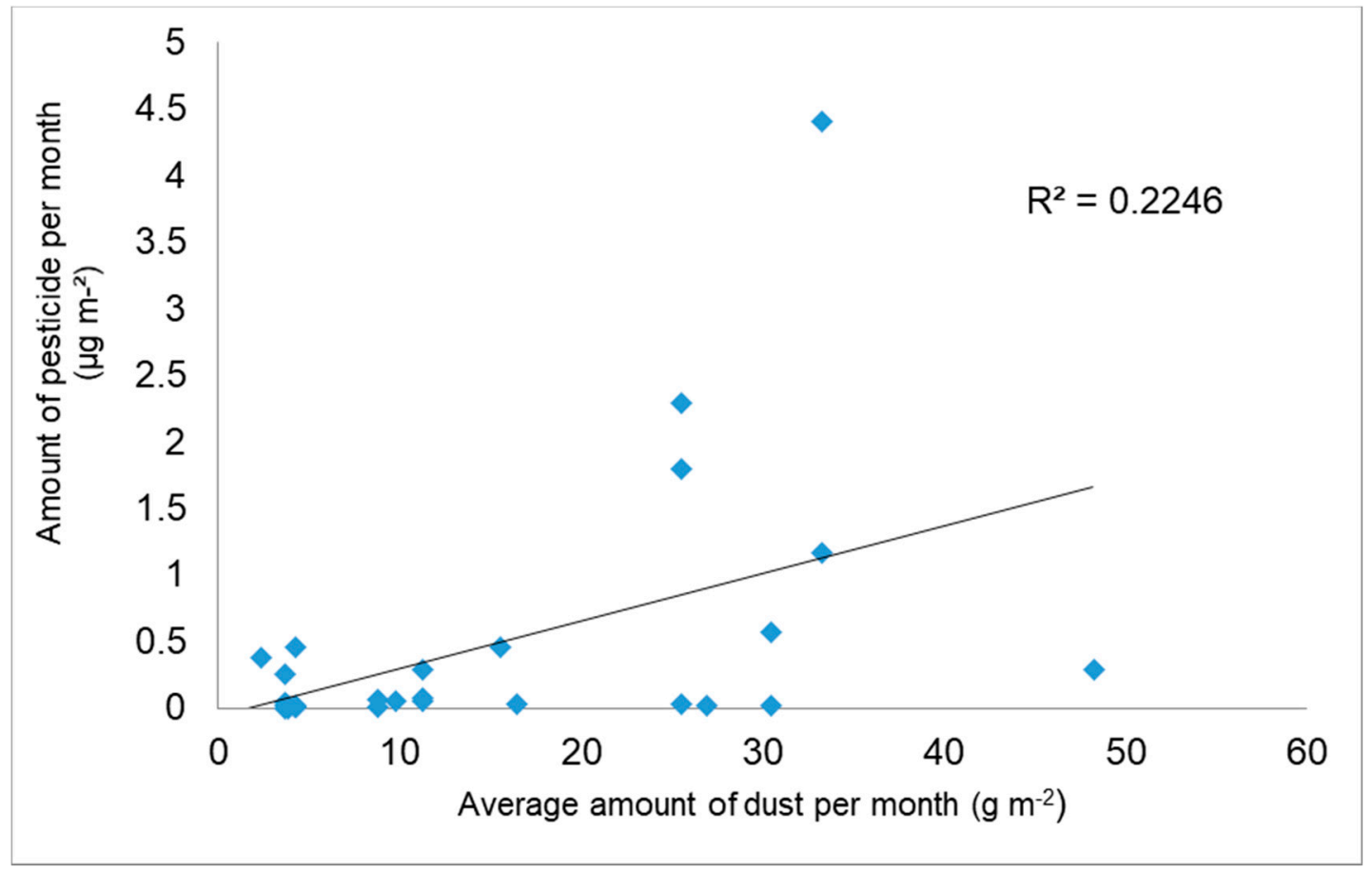

Figure A3. Correlation between the amount of pesticide per month $\left(\mu \mathrm{g} \mathrm{m}^{-2}\right)$ and the amount of dust per month $\left(\mathrm{g} \mathrm{m}^{-2}\right)$.

\section{References}

1. Van der Werf, H.M.G. Assessing the impact of pesticides on the environment. Agric. Ecosyst. Environ. 1996, 60, 81-96. [CrossRef]

2. Alavanja, M.C.R. Pesticides use and exposure extensive worldwide. Rev. Environ. Health 2009, 24, $303-309$. [CrossRef] [PubMed] 
3. Carson, R. Silent Spring; Riverside Press: Cambridge, MA, USA, 1962.

4. Severn, D.J.; Ballard, G. Risk/benefit and regulations. In Pesticides in the Soil Environment: Processes, Impacts and Modeling; Book Series No. 2; Soil Science Society of America: Madison, WI, USA, 1990; pp. 467-491.

5. Emans, H.J.B.; Beek, M.A.; Linders, J.B.H.J. Evaluation System for Pesticides (ESPE) I. Agricultural Pesticide; Rep. No. 679101004; National Institute of Public Health and Environmental Protection (RIVM): Bilthoven, The Netherlands, 1992.

6. European Commission. EU Pesticides Database. Available online: http://ec.europa.eu/food/plant/ pesticides / eu-pesticides-database/public/? event=homepage\&language=EN (accessed on 7 April 2016).

7. Taylor, A.W.; Spencer, W.F. Volatilization and vapor transport processes. In Pesticides in the Soil Environment: Processes, Impacts and Modeling; Book Series No. 2; Soil Science Society of America: Madison, WI, USA, 1990; pp. 213-269.

8. Ucar, A.; Hall, F.R. Windbreaks as a pesticide drift mitigation strategy: A review. Pest Manag. Sci. 2001, 57, 663-675. [CrossRef] [PubMed]

9. Young, S.L. Natural Product Herbicides for Control of Annual Vegetation Along Roadsides. Weed Technol. 2004, 18, 580-587. [CrossRef]

10. Arias-Estevez, M.; López-Periago, E.; Martínez-Carballo, E.; Simal-Gandara, J.; Mejuto, J.C.; Garcia-R1o, L. The mobility and degradation of pesticides in soils and the pollution of groundwater resources. Agric. Ecosyst. Environ. 2009, 123, 247-260. [CrossRef]

11. Pimentel, D. Amounts of pesticides reaching target pests: Environmental impacts and ethics. J. Agric. Environ. Ethics 1995, 8, 17-29. [CrossRef]

12. Schomburg, C.J.; Glotfelty, D.E. Pesticide occurrence and distribution in fog collected near Monterey, California. Environ. Sci. Technol. 1991, 25, 155-160. [CrossRef]

13. Gregor, D.J.; Gummer, W.D. Evidence of atmospheric transport and deposition of organochlorine pesticides and polychlorinated biphenyls in Canadian arctic snow. Environ. Sci. Technol. 1989, 23, 561-565. [CrossRef]

14. Walker, A. Simulation of herbicide persistence in soil. Pestic. Sci. 1976, 7, 41-49. [CrossRef]

15. Atlas, E.L.; Schauffler, S. Concentration and variation of trace organic compounds in the north pacific atmosphere. In Long Range Transport of Pesticides; Kurtz, D.A., Ed.; Lewis Publishers: Chelsea, MI, USA, 1990; pp. 161-183.

16. Leonard, R.A. Movement of pesticides into surface waters. In Pesticides in the Soil Environment: Processes, Impacts and Modeling; Book Series No. 2; Soil Science Society of America: Madison, WI, USA, 1990; pp. 303-349.

17. Paterson, S.; MacKay, D.; Tam, D.; Shiu, W.Y. Uptake of organic chemicals by plants: A review of processes, correlations and model. Chemosphere 1990, 21, 297-331. [CrossRef]

18. Environmental Protection Agency of U.S. (EPA)—Drift Reduction Technology Program. Available online: https:/ / www.epa.gov/reducing-pesticide-drift/about-drift-reduction-technology-program (accessed on 7 July 2017).

19. Hall, F.R.; Fox, R. The reduction of pesticide drift. In Pesticide Formulation and Adjuvant Technology, 1st ed.; Foy, C.L., Pritchard, D.W., Eds.; CRC Press: London. UK, 1996; pp. 209-239.

20. Muscutt, A.D.; Harris, G.L.; Baily, S.W.; Davies, D.B. Buffer zones to improve water quality: A review of their potential use in UK agriculture. Agric. Ecosyst. Environ. 1993, 45, 59-77. [CrossRef]

21. Reichenberger, S.; Bach, M.; Skitschak, A.; Frede, H.G. Mitigation strategies to reduce pesticide inputs into ground and surface water and their effectiveness: A review. Sci. Total Environ. 2007, 384, 1-35. [CrossRef] [PubMed]

22. Sabbagh, G.J.; Muñoz-Carpena, R.; Fox, G.A. Distinct influence of filter strips on acute and chronic pesticide aquatic environmental exposure assessments across U.S. EPA scenarios. Chemosphere 2013, 90, 195-202. [CrossRef] [PubMed]

23. Popov, V.H.; Cornish, P.S.; Sun, H. Vegetated biofilters: The relative importance of infiltration and adsorption in reducing loads of water-soluble herbicides in agricultural runoff. Agric. Ecosyst. Environ. 2005, 114, 351-359. [CrossRef]

24. Jaeken, P.; Debaer, C. Risk of water contamination by plant protection products (PPP) during pre- and post-treatment operations. Annu. Rev. Agric. Eng. 2005, 4, 93-114. 
25. Vanderstraeten, P.; Lénelle, Y.; Meurrens, A.; Carati, D.; Brenig, L.; Offer, Z.Y.; Zaady, E. Micromorphology and Chemistry of airborne particles during agriculture working periods in Brussels surrounding region. Environ. Monit. Assess. 2007, 146, 33-39. [CrossRef] [PubMed]

26. Makarov, V.I.; Ankilov, A.N.; Koutsenogii, K.P.; Borodulin, A.I.; Samsonov, Y.N. Efficiency of the inertial wind capture of pesticide aerosols by vegetation species. J. Aerosol Sci. 1996, 27, 67-68. [CrossRef]

27. Tyndall, J.; Colletti, J. Mitigating swine odor with strategically designed shelterbelt systems: A review. Agrofor. Syst. 2006, 69, 45-65. [CrossRef]

28. Grala, R.K.; Tyndall, J.C.; Mize, C.W. Impact of field windbreaks on visual appearance of agricultural lands. Agrofor. Syst. 2010, 80, 411-422. [CrossRef]

29. Reimer, A.P.; Prokopy, L.S. Environmental attitudes and drift reduction behavior among commercial pesticide applicators in a U.S. agricultural landscape. J. Environ. Manag. 2012, 113, 361-369. [CrossRef] [PubMed]

30. Vanella, G.; Salyani, M.; Balsari, P. Spray interactions with a windbreak netting used in orchard applications. Crop Protect. 2013, 44, 95-103. [CrossRef]

31. Bouvet, T.; Loubet, B.; Wilson, J.D.; Tuzet, A. Filtering of windborne particles by a natural windbreak. Boundary-Layer Meteo. 2007, 123, 481-509. [CrossRef]

32. Uni, D.; Katra, I. Airborne dust absorption by semi-arid forests reduces PM pollution in nearby urban environments. Sci. Total Environ. 2017, 598, 984-992. [CrossRef] [PubMed]

33. Richards, J.; Reif, R.; Luoc, Y.; Gana, J. Distribution of pesticides in dust particles in urban environments. Environ. Pollut. 2016, 214, 290-298. [CrossRef] [PubMed]

34. Israel Meteorological Service. Available online: http://www.ims.gov.il/IMSENG/All_Tahazit/homepage. htm (accessed on 13 July 2018).

35. Offer, Z.; Zaady, E.; Shachak, M. Aeolian particles input to soil surface at the northern limit of the Negev desert. Arid Land Res. Manag. 1998, 12, 55-62. [CrossRef]

36. Zaady, E.; Offer, Y.Z.; Shachak, M. The content and contribution of the accumulated aeolian organic matter in a dry ecosystem. Atmos. Environ. 2001, 35, 769-776. [CrossRef]

37. Tanner, S.; Katra, I.; Haim, A.; Zaady, E. Quantification of short-term soil loss by aeolian erosion in response to conventional and organic agricultural practices. Soil Tillage Res. 2016, 155, 149-156. [CrossRef]

38. Martel, A.C.; Lair, C. Validation of a highly sensitive method for the determination of neonicotinoid insecticides residues in honeybees by liquid chromatography with electrospray tandem mass spectrometry. Int. J. Environ. Anal. Chem. 2011, 91, 978-988. [CrossRef]

39. Eiserbeck, C.; Nelson, R.K.; Grice, K.; Curiale, J.; Reddy, C.M. Comparison of GC-MS, GC-MRM-MS, and $\mathrm{GC} \times \mathrm{GC}$ to characterise higher plant biomarkers in Tertiary oils and rock extracts. Geochim. Cosmochim. Acta 2012, 87, 299-322. [CrossRef]

40. Simcox, N.J.; Fenske, R.A.; Wolz, S.A.; Chwen Lee, I.; Kalman, D.A. Pesticides in household dust and soil: Exposure pathways for children of agriculture families. Environ. Health Perspect. 1995, 103, 1126-1134. [CrossRef] [PubMed]

41. Kok, J.F.; Parteli, E.J.R.; Michaels, T.I.; Karam, D.B. The physics of wind-blown sand and dust. Rep. Prog. Phys. 2012, 75, 106901. [CrossRef] [PubMed]

42. Swet, N.; Katra, I. Reduction in soil aggregation in response to dust emission processes. Geomorphology 2016, 268, 177-183. [CrossRef]

43. Bollen, W.B. Interactions between pesticides and soil microorganisms. Annu. Rev. Microbiol. 1961, 15, 69-92. [CrossRef]

44. Audus, L.J. Herbicide behaviour in the soil. II Interactions with soil microorganisms. In The Physiology and Biochemistry of Herbicides; Audus, L.J., Ed.; Academic Press: New York, NY, USA, 1964; pp. 163-206.

(C) 2018 by the authors. Licensee MDPI, Basel, Switzerland. This article is an open access article distributed under the terms and conditions of the Creative Commons Attribution (CC BY) license (http:/ / creativecommons.org/licenses/by/4.0/). 